\title{
LEGAL PROTECTION ON CHILDREN AS VICTIMS OF HUMAN TRAFFICKING BASED ON JUSTICE VALUES
}

\author{
Anis Mashdurohatun \\ Faculty of Law, Sultan Agung Islamic University \\ anism@unissula.ac.id \\ Wa Ode Khatija Rasia \\ Postgraduate Student in UNISSULA \\ rasiawaode@std.unissula.ac.id
}

\begin{abstract}
The purpose of this study is to examine and analyze the factors that affect the legal protection of children as victims of human trafficking and to formulate legal protection based on the value of justice. The approach method used in this study was normative juridical, which the data source came from secondary data, consisting of primary, secondary and tertiary legal materials. The research finds that the factors that most influence the occurrence of crime children trafficking are economic factors and cultural factors of society. Legal protection of children as victims of human trafficking based on justice values, preventively establishing various laws and regulations, cooperating and coordinating among state institutions, engaging in international cooperation and socializing the public about the dangers of human trafficking. And repressively impose sanctions that are oriented to the victim.
\end{abstract}

Keywords: Legal protection, child as victim, human trafficking.

\section{A. INTRODUCTION}

The rise of cases of violence against children and child trafficking are due to the not optimal child protection efforts undertaken. Cases of child trafficking also tend to increase over the period from 2010 to 2012 , there were 410 cases in 2010 increased to 480 cases in 2011 and to 673 cases in 2012. Indonesia is a source, transit and destination country of trafficking to women and children, especially for the purpose of prostitution and exploitation of children. The phenomenon of trafficking in adults is increasingly diverse forms and modes. Many prostitutes in both localization and covert places of prostitution such as cafés, massage parlors, plus-plus beauty parlors, hotels and others began to mushroom, both in big cities and in rural areas. ${ }^{1}$

Lihat Artikel "Temuan dan Rekomendasi KPAI tentang Perlindungan Anak Dibidang Perdagangan Anak (Trafficking) dan Eksploitasi Terhadap Anak", $\mathrm{KPAI}$, dalam http://www.kpai.go.id/artikel/temuandan-rekomendasi-kpai-tentang-perlindungananak-di-bidang-perdagangan-anak-trafficking-daneksploitasi-terhadap-anak/ di akses pada hari rabu, tanggal 30 November 2016 pukul 10.32 WIB.
Data were obtained from the findings of BARESKRIM POLRI (National Police Criminal Investigation Unit) on human trafficking cases especially children. It found that in the time frame of 2010-2013 there were 467 cases of human trafficking, where the number of children who became victims of human trafficking and exploitation of 197 children were mostly girls. In 2011, the number of human trafficking cases was 205 cases, of which 87 girls were victims. In 2012 the number of human trafficking cases were 192 cases, where the number of female victims were 71 children and there were 1 (one) boy and in 2013 the number of human trafficking cases were 70 cases where the number of children women victims of as many as 40 children.

Details of data from KPAI (child and mother protection commissions) on human trafficking cases with children as victims in 2015 stated that, in 2015 children as trafficking victims amounted to 48 or $16.6 \%$. In January there were 3 children as victims of trafficking, in February there were 2 children, in March there were 5 children, in April there were 4 children, there were 4 children in 
May, there were 9 children in June, there are 8 children in July, the month of August there were 4 children, in September there were 2 children, children, November there were 2 children, and boasting December there were 2 children as victims of trafficking. From the data in June and July cases of human trafficking with children as victims increased as much as 9 and 8 children.

In essence, child protection is a result of interaction due to the interrelation between existing phenomena and mutual influence. For the sake of the implementation of child protection rationally positive, responsible and useful, then the issue of child protection needs to be reviewed and understood according to the actual proportion dimensional. Need to be understood and disseminated understanding and thoughts about human, justice, rights and obligation, personal interest and national interest and other positive thoughts which can be our guidance to behave and act to participate in the implementation activity of child protection. Implementation of child protection covering the various areas of life services that must be done together requires a coordination organization. ${ }^{2}$ Thus, based on the background of the above problem, it is necessary to conduct research on the importance of deeply examining of the factors causing the crime of children trafficking and the protection of the law of children as the victims of justice-based trafficking.

\section{B. DISCUSSION}

1. Legal Protection against Children as Human Trafficking Victims Viewed From Law Number 21 Year 2007 on the Eradication of Criminal Act of Human Trafficking.

Child protection is an undertaking in which any child may do his rights and obligations. This protection is a manifestation of justice in society, protecting children is protecting human beings. Thus, the protection of children should be cultivated in various areas of state and community life.

Protection of children in a society is

2 Arif Gosita, 2007, "Masalah Korban Kejahatan", FHUI Cet. Ke IV, Jakarta, page 215 a benchmark of civilization society, in a particular nation. So, for the sake of the development of the whole person, we must endeavor to protect children according to ability, for the sake of the people and nation. Child protection activities are legal actions that bring legal consequences. Therefore, there is a need for legal guarantee for the child protection activities. ${ }^{3}$

a. Legal Protection against Children From Investigation, Prosecution and Judicial Review

In the case of human trafficking crime which the victim is a child, the law enforcement officer in conducting investigation, prosecution and examination through trial in court must be done specifically. Further, its implementation is not equated with investigation, prosecution, and examination of the adult person. It should be done separately and done with due regard to the best interests of the child. For more details regarding the above matter is regulated in Article 38 of Law Number 21 Year 2007 on the Eradication of Crime of Trafficking in Persons.

In a hearing for a human trafficking crime case where the witness and / or his corpse is a child, it must be closed and must be accompanied by a parent, guardian, foster parent, advocate, or other assistant and performed without the presence of the defendant. For more details on the above matter is regulated in Article 39 of Law Number 21 Year 2007 on the Eradication of Crime of Human Trafficking.

In examining human trafficking cases against witnesses and/or child victims, in order to observe the best interests of the child, the examination may be conducted outside the court

Didi Sukardi, "Perlindungan Hukum anak Korban Penelantaran Orang Tua Berbasis Hukum Positif dan Islam", Mahkamah, Vol.1 No.2 Desember 2016, E-ISSN: 2502-6595, page 186-187. 
with the consent of the judge and conducted in the presence of the competent authority. For more details on the above matter is regulated in Article 40 of Law Number 21 Year 2007 on the Eradication of Crime of Human Trafficking.

b. Legal Protection Against Children in the Provision of Replacement and Recovery of Human Trafficking Victims

Children who are victims of human trafficking or their heirs are entitled to receive restitution or compensation from human trafficking offenders for loss of property or income, suffering, costs for medical and/or psychological treatment and/or other injuries suffered by victims as a result of human trafficking through court proceedings. The restitution shall be made within 14 (fourteen) days from the date on which the decision is obtained which has obtained a permanent legal force. In the case of a human trafficking does not decided to free by perpetrator or cassation court. For more details regarding the above matter is regulated in Article 48 of Law Number 21 Year 2007 on the Eradication of Crime of Human Trafficking.

Children who become victims of human trafficking crime suffer a lot of physical, mental, psychological, sexual, economic and social suffering due to actions by irresponsible people so that many victims of human trafficking crime who suffer from health problems, stress, depression and even to end on death. Therefore victims of human trafficking are entitled to health rehabilitation, social rehabilitation, repatriation, and social reintegration from the government. For more details regarding the above matter is regulated in Article 51 of Law Number 21 Year 2007 on the Eradication of Crime of Human Trafficking. c. Legal Protection Against Children from Criminal Aspect Against Human Trafficking Criminal Actor

There are many modes are done by the perpetrators of human trafficking crime to get children. These children will be changed as a trafficking object, one of which is by adoption of children. The perpetrators come to the affected areas, conflicts and poor districts to launch their actions by helping children who have lost their parents to natural disasters by raising them as children and promising happiness in order to exploit the child. For more details on the above matter is regulated in Article 5 of Law Number 21 Year 2007 on the Eradication of Crime of Human Trafficking.

Children who become victims of human trafficking are initially experienced fraud by being promised and lured to be given good jobs with high salaries in certain places still in the country of Indonesia and places that are outside Indonesia. The targets are children who are below the poverty line and low educated then usually the families of these children without thinking immediately believe and agree with the false promises given. If the victim has been affected and agrees with the trick of the human trafficking offender, the perpetrator sends the children to the places that have been promised with the intention to be exploited. For more details on the above matter is regulated in Article 6 of Law Number 21 Year 2007 on the Eradication of Crime of Human Trafficking.

Children victims of human trafficking are often subjected to violence from where they work, so that many victims suffer severe physical injuries, severe mental illness, and other infectious diseases. All of 
those diseases endanger their lives, pregnancy, or disruption or loss of their reproductive function, resulting in casualties stress, depression and even lead to death. For more details on the above matter is regulated in Article 6 of Law Number 21 Year 2007 on the Eradication of Crime of Human Trafficking.

In the case of human trafficking crimes there are certain elements of state officials who abuse their power to be involved in human trafficking. This is because the business of human trafficking is one of the biggest profit business besides narcotics business. This is unfortunate and very regrettable because the state organizers should play an active role in preventing and overcoming the occurrence of human trafficking crimes, but instead participate and help launch the human trafficking crime, this will result in lack of public trust to the state apparatus. For more details regarding the above matters is regulated in Article 8 of Law Number 21 Year 2007 on the Eradication of Crime of Human Trafficking.

In conducting of human trafficking crime, usually the perpetrator is not only one or two persons but more than that. Even the implementation of human trafficking organized in groups, and if deemed necessary in certain conditions to get a sense of security the perpetrator. Sometimes move others to commit a crime human trafficking. For more details on the above matter is regulated in Article 9 of Law Number 21 Year 2007 on the Eradication of Crime of Human Trafficking.

If a person commits a criminal act of human trafficking and has fulfilled all the elements as meant in Article 2, Article 3, and Article 4 and the offense is committed against the child then the criminal threat is added $1 / 3$ (one third). For more details on the above matter is regulated in Article 17 of Law Number 21 Year 2007 on the Eradication of Human Trafficking Crime.

In the implementation of Law Number 21 Year 2007 based on the analysis of the author in Decision of Manado District Court Number: 331 / Pid. B / 2011 / PN.MDO, the legal protection of the child from the point of indemnification provided for in Article 48 , and the legal protection of the child from the point of punishment of the perpetrators provided for in Articles $5,6,7,8,9$ and 17. It cannot be properly realized by law enforcement officers, especially prosecutors and judges. Judge and Prosecutor did not mention the matter of restitution (loss). Based on the statement from witness Irianto Nusi who is the father of the victim, he stated that the victim is still experiencing trauma due to the crime he experienced, while in Article 48 clearly stated that the child who became the victim of the crime human trafficking shall be entitled to restitution or compensation from a human trafficking offender for loss of property or income, suffering, expenses for medical and / or psychological treatment and/or other damages suffered by the victim. Similarly, in imposing sanction of imprisonment and criminal sanction, the defendant has committed a crime of human trafficking against a child based on the provisions of Article 17 which read "If the crime of trafficking as intended to be done to the child, the criminal threat is added $1 / 3$ (one third). But in the trial the judge handed down the sanction of imprisonment and the fine to the Defendant SRI SISKA WATI NANI alias TATA with imprisonment for 3 (three) years and a fine of Rp.120.000.000, - (one hundred twenty million rupiah ). With 
note that such a fine is not paid, it can be replaced with a 6-month prison term. So, the judge should have sent the prison sentence to the defendant over 3 (three) years as well as the penalty fine but which happened instead.

Actually, the legal protection of children as victims of human trafficking given by Law Number 21 Year 2007 is currently not optimal due to various obstacles and challenges. In the application to the community, especially to the victims, always blocking in various forms, quantity and quality, which of course must be found a way out. One of the obstacles is the weakness of law enforcement against the perpetrators of human trafficking. Involves many parties such as the police in the location of the victim was found, the process of police investigation report (BAP) takes a long time and the average victim is low educated. Therefore, in the examination must be repeated and the number of trafficking cases that have not been touched the law because the victim's family is not cooperative in providing information about the perpetrators. Even they tend to protect the perpetrators. In addition to the lack of attention from the government to victims of human trafficking crimes in the fulfillment of the rights of victims most of what happens in the community. Legal protection to the victim is given only limited to punish the perpetrator but in addition to punish the perpetrator there are some things that must be considered by the government in providing protection to victims one of them. The fulfillment of the rights of the victim over their recovery is due to the crime that befell them, so that it can return to normal. There are many people who do not understand about the laws and regulations that regulate the current criminal human trafficking is therefore necessary to provide understanding and socialization to the public so that if an event is allegedly going to lead to the practice of trafficking in persons then the people have to know what to do and must report where.

\section{Causes of Crime of Children Trafficking}

Of all forms of trafficking, children trafficking are a form of commerce that receives the greatest attention and criticism from all countries in the world. Countries around the world made several attempts to prevent children trafficking, especially trade for the purpose of sexual exploitation. Other forms of child trafficking for purposes of sexual exploitation are also as beggars, news agents, domestic helpers (especially in Haiti), mining, agriculture, illegal adoption (especially in Costa Rica and the Dominican Republic), and child soldiers (in Columbia). Since children trafficking attract enormous attention, child traffickers often forget about their age by forcing victims to lie about their age and falsifying identity papers of victims. In addition, significant difficulties in identifying child trafficking as in Latin American countries arose from differences in legal age for women in the country, which averaged from fourteen years, to the age of eighteen given by the Palermo Protocol. ${ }^{4}$

Factors that cause human trafficking are driven by economic needs, either for survival or a desire for a better life. Thus, human trafficking is not only on the path of clear destination countries of the United States, Canada, and Europe, but from poorer regions to more prosperous regions. This includes movements from village to city, then from poorer urban areas to more affluent areas within or outside of countries of origin. ${ }^{5}$

4 David E. Guinn, "Defining the Problem of Trafficking: The Interplay of US Law, Donor, and NGO Engagement and the Local Context in Latin America", Vol. 30, page 124-125.

5 Ibid, page 130 
Trafficking of women and children for the purpose of economic and sexual exploitation is an organized transnational crime of corporations, syndicates and crime. People traders use several methods including violence, coercion and fraud to achieve their goals by moving victims from their homes and families to places where they are forced to work as domestic servants, prostitutes, farm workers, factory workers and some of them the trafficked are children and women, including men. ${ }^{6}$

With the increasing population in the world where economic development and labor supply and social infrastructure for self-development, society, and national progress have not materialized, individuals are desperate to survive so tempted to engage in criminal and unfit activities for economic survival. Broadly speaking, factors such as population increase, poverty, inequalities in the distribution of basic resources, gender inequality, child devaluation, and strict and complex immigration laws have caused many people, especially women and children vulnerable to trafficking in persons who smuggle them into other countries. According to records available from the US Department of State in 2006 each year nearly one million people (about 800,000 children, women, and men with at least $80 \%$ are women, and $50 \%$ small children) are trafficked across the border international for economic and sexual exploitation. ${ }^{7}$

Below is a table about the factors causing the crime of children trafficking:

\begin{tabular}{|c|c|c|c|c|}
\hline \multicolumn{5}{|c|}{ Factors Causing Children Trafficking } \\
\hline \multirow{2}{*}{ No } & $\begin{array}{c}\text { General Factors } \\
\text { that cause child } \\
\text { trafficking }\end{array}$ & $\begin{array}{c}\text { Factors causing children trafficking based on } \\
\text { KPAl monitoring and evaluation results in 2012 }\end{array}$ & $\begin{array}{c}\text { Causes of human } \\
\text { trafficking (children) } \\
\text { based on ILO-IPEC } \\
\text { research results in 2003 }\end{array}$ \\
\cline { 3 - 4 } & Poverty & Geographical & $\begin{array}{c}\text { Advances in information } \\
\text { technology and } \\
\text { transportation }\end{array}$ & Quality of Life \\
\hline 2 & Ketenagakerjaan & Economics & $\begin{array}{c}\text { The increasing need of } \\
\text { overseas workers }\end{array}$ & Consumerism \\
\hline 3 & Education & $\begin{array}{c}\text { Social and } \\
\text { Culture }\end{array}$ & $\begin{array}{c}\text { Agencies of migrant workers } \\
\text { in foreign countries that are } \\
\text { not covered by supervision }\end{array}$ & Community's behavior \\
\hline 4 & Migration & Security & $\begin{array}{c}\text { The competent value of } \\
\text { Indonesian migrant workers } \\
\text { is lower }\end{array}$ & Mass Media \\
\hline 5 & $\begin{array}{c}\text { Family's } \\
\text { Condition }\end{array}$ & & Abuse of Employment & \\
\hline 6 & Social and & & Weaknesses of Diplomacy & \\
\hline 7 & Mass Media & & & \\
\hline
\end{tabular}

\begin{tabular}{|c|c|c|c|}
\hline \multicolumn{4}{|c|}{ Factors Causing Crime of Children Trafficking Based on Analysis of Some Court Decisions } \\
\hline No & $\begin{array}{c}\text { Decision Number: No.331/ } \\
\text { Pid.B/2011/PN.MDO }\end{array}$ & $\begin{array}{c}\text { Decision Number: 107/ } \\
\text { Pid.B/2013/PN. KNG, }\end{array}$ & $\begin{array}{c}\text { Decision Number: } \\
\text { 2401 K/Pid.Sus/2014 }\end{array}$ \\
\hline 1 & Victim of Fraud & Economic Factor & Work Factor to meet the needs of life \\
\hline 2 & & Life Style Factor & \\
\hline
\end{tabular}

6 O. Oko Elechi, T.Y. Okosun, and Job E. Ngwe, "Factors Vitiating Against the Effectiveness of the Nigeria Police in Combating the Criminal Exploitation of Children and Women",AJCJS; Volume 3, No. 1, July 2007, ISSN 15543897, page 2-3.

7 Ibid. page 3-4. 
Factors causing the crime of children trafficking are as follows:

a. In Decision Number: 107 / Pid.B / 2013 I PN. KNG, the factors causing the acts of pida children trafficking are as follows:

1. Economic Factors

Based on legal facts found in the trial Ayu Novita victims will accept the offer of defendant Novita Sari binti Dodo (Defendant) because the victim is in need of money to pay school tuition.

From these problems prove that the economic factor is one of the most important factors compared with other factors that cause the occurrence of crime. The poor economic condition of the family is classified as poor family can cause the child become easy target for the perpetrators of human trafficking crime in launching the action and the child who is trapped in an urgent situation such as having to pay the tuition fee to be able to continue the school will be faced on two choices that is refused or accept the offer of the perpetrators of the human trafficking crime with the consequences to be borne alone by the child, because the child is caught in an urgent situation requiring him to take a criminal choice in solving the problems he is facing.

Based on the above provisions on the factors causing the crime of children trafficking, when viewed from the side of criminology, it is matching the theory as follows:

"The theory which is not oriented to social class is " theory of economic factors". One of the most famous and widely followed studies is $\mathrm{G}$. Von Mayr (1841-1925) who has been studying the relationship between stealing and the price of wheat at Bayern during 1835-1861. It shows a high correlation between the rise in wheat prices and crime against property, begging, and emigration. Furthermore Von Mayr says almost every increase of 0.5 penny grain price will result in an increase of one theft per 100,000 population and a decrease in the number of crimes against people, and vice versa. By Von Mayr this is due to what is referred to as "Objective Nahbrungserchwerung", that is because the price of food is increasingly expensive so that more people cannot meet their most important needs. ${ }^{8}$

So the economic condition of the poor families is classified as poor families, when faced with the increasing needs of life in the present, such as one must pay tuition in order to continue the school then the individual will feel desperate to survive so tempted to engage in criminal and activities that are not feasible to survive economically.

2. Lifestyle Factors

Based on the testimony of one witness named Fitria binti Nadi, said that the Defendant has also offered a male guest 3 times but only 1 offer ever received by him. Fitria bint Nadi to make intercourse with the guest with a fee of Rp. 70.000 , -and the most concern is Fitria binti Nadi want to do the act because the witness needs money for the daily snack, because the money that the witness get from the parent is still lacking.

Consumptive lifestyle behavior is the most common factor. People tend to justify any means to meet their needs. Especially for the lifestyle of teenagers who started in the school or at home can cause consumptive behaviors that must lead to negative things. If one cannot keep up with the lifestyle, it will be followed by a crime factor. In addition, parents become factors that encourage perpetrators.

8 I.S. Susanto, 2011, "Kriminologi”, Genta Publishing, Yogyakarta, page 87-88. 
Consumptive lifestyles dominate the society lately. The concern, because of the weak economy and the demands of a high lifestyle, becomes a fundamental factor of trafficking. Should teenagers and the general public should be able to control themselves to reduce the consumptive lifestyle. The rise of trafficking cases that affect teenagers, who are made into commercial sex workers, sometimes motivated by the victim's desire to fulfill the necessities of life, such as cool HP, good clothes, even money to splurge.

Based on the above provisions on the factors causing the crime of children trafficking then when viewed from the side of criminology then it is in line with:

"Sociological Theory" Sociological theories can be grouped into three general categories: Strain, Culture deviance, and social control.

Strains theory and cultural deviation continue to assume that social class and criminal behavior are related, but different in terms of the nature of the relationship. The adherents of strain theory assume that all members of society follow a set of cultural values that is the cultural values of the middle class. One of the most important cultural values is economic success. Because people from the lower classes do not have the legitimate means to achieve that goal, they become frustrated and switch to using illegitimate means in the decision. ${ }^{9}$

Thus, co $n$ sumptive lifestyle behavior is the most influencing factor of the occurrence of criminal acts, especially for adolescents, lifestyles that begin in school or at home can lead to consumptive behaviors that

Topo S a ntoso dan Eva Achjani Zulfa, 2011, "Kriminologi", PT Rajagrafindo Persada, Cet. Ke II, Jakarta, page 57-58. must lead to negative things. If one cannot compensate for a lifestyle such as following a more popular current or following a high-economic lifestyle, it will be followed by a crime factor.

b. In Decision Number: No.331 / Pid.B / 2011 / PN. MDO factors causing acts of criminal children trafficking are as follows:

1. As a Victim of Fraud

In this case the defendant SRI SISKA WATI NANI GIASI or TATA and her colleagues committed a human trafficking crime by deceiving the victims by promising to work as public relations, Dancer, Model, DJ and boy band with a salary offer of Rp.1.500. 000, - (one million five hundred thousand rupiah) as well as bonuses totaling Rp.8.000.000, - (eight million rupiah) and the workplace will get facilities such as Mess, Laundry and meals. But in reality the victims were employed as Ladies who served to accompany the drinking guests, karaoke, offering drinks with sexy dress and getting tip given by the guest Rp.750.000, - (seven hundred fifty thousand rupiah).

c. In Decision Number: $2401 \mathrm{~K} /$ Pid. Sus/2014 the factors causing the occurre nce of acts pida children traffic king are as follows:

1. Working Factors to meet the needs of life

In this case, children are exploited econom ically and sexually by irresponsible persons only to fulfill their own personal interests and for the benefit of certain persons. The defendant TINI binti ATIM employs minors using false identities and is placed at a shelter where the children are named WANTINI aka TINI, ALVIA FENI RAHAYU binti SIMAN, SENTIA DEWI aka TIA, EFA YULIANTI binti SIMAN and SAMINEM aka SAMI in The Sauna \& Spa Massage Center where the place is not a suitable 
place for children to work where the children have to work as a masseur and besides also work to provide sexual services when asked by the guests or patients in the form of intercourse.

This increasingly modern life is in line with the more increasing the necessities of life both urban and rural. Therefore, for families whose economic conditions are low to meet the daily needs of the child is forced to be involved in helping both people know to make a living. The condition is so fresh again new things happen in Indonesian society. Many children are faced with a choice between school and work, so there are not many children who drop out and prefer to work for a living because the child is trapped in the conditions of life that require him to work. This is certainly very unfortunate considering the child is the next generation of the nation that will determine the good of the nation in the future so the child is entitled to get the lessons and teaching to finish in accordance with his rights as an Indonesian citizen.

3. Legal Protection of children as victims of Human Trafficking based on Justice Values

Certain criminal justice processes of children are often unable to develop their rights due to certain matters and thus need to receive assistance and protection in the exercise of their rights and obligations. Thus, the protection of the child includes, among others, the protection of the exercise of the rights and obligations of the child in a balanced and humane way. This is in line with the notion: "Child protection is an endeavor that protects a child from exercising its human rights responsibly in a balanced and humane way". The embodiment of protection here is among others coaching, facilitation, inclusion, supervision, prevention, arrangement, educational, constructive, integrative, creative and positive guarantees and this effort does not ignore the mental, physical, social aspects of a person. ${ }^{10}$

Protection of children as victims of human trafficking by preventive and repressive is as follows:

\section{a. Regulation Hierarchy of Legal Protection against Human Trafficking}

1. The 1945 Constitution of the State of the Republic of Indonesia in Article 28B paragraph 2.

2. The Decree of the People's Consultative Assembly TAP MPR Number XVII of 1998 on Human Rights (HAM).

3. Legislation

The laws and regulations governing the crime of trafficking in persons are as follows:

a. Law Number 39 Year 1999 on Human Rights (HAM)

b. Law Number 21 Year 2007 Concerning the Eradication of Trafficking in Persons.

c. Law Number 23 Year 2002 Jo Law Number 35 Year 2014 About Child Protection.

d. The Criminal Code (Penal Code)

4. Government Regulation

Government Regulation governing the Crime of Human Trafficking is Government Regulation Number 9 Year 2008 About Procedures and Mechanism of Integrated Services for Witnesses or Victims of Trafficking Crime People.

Joint Agreement among State Minister of Women Empowerment, Minister of Health, Minister of Social Affairs and Chief of Police of RI Number: 14 / Men.PP / Dep.v /

10 Ririen Ambarsari, Faniko Andiyansyah, Anugrah Adiputro Soewandi, "Kajian Yuridis Tentang Perlindungan Hukum Terhadap Perempuan dan Anak Korban Human Trafficking" Vol.1 No.1 Juni 2016 ISSN: 2527-6654, page. 71. 
X / 2002; 1329 / MENKES / SKB / X/2002; 75 / HUK / 2002; POL.B / 3048 / X / 2002 on the Integrated Services of Victims of Violence Against Women and Children, realized by establishing Integrated Service Centers at several Central and Regional public hospitals and Police hospitals, so that victims can easily access services required both medical aspects, psychological, as well as social and legal aspects. As the implementer of Integrated Service Center are doctors and related nurses, psychologists, POLRI investigators, and can work together with social workers in an integrated manner under the coordination of the leadership of the Center of Integrated Services concerned. ${ }^{11}$

5. Presidential Regulation

a. Presidential Regulation stipulating Crime of Child Trafficking is PERPRES No. 69 Year 2008 About Task Force of Prevention and Handling of Crime of Trafficking of Persons.

a. Presidential Decree No. $88 / 2002$ on the National Action Plan for the Elimination of Trafficking of Women and Children.

b. Besides the Establishment of Laws and Regulations As Provisions Above Other Acts by the Government are as follows:

b. Besides the Establishment of Laws and Regulations As Provisions Above Other Acts by the Government are as follows:

1. The Government Conducted a "National Coordination Meeting

11 Ahmad Syaufi, "Perlindungan Hukum Terhadap Perempuan dan Anak Korban Tindak Pidana Perdagangan Orang", Muwazah, Vol.3, No.2, Desember 2011, page 462-463. on the Protection of Women and Children" in 2013 which takes place in Bali with 11 (eleven) resource persons from different state institutions such as the Ministry of Women Empowerment and Child Protection, Ministry of Law and Human Rights, Ministry of Foreign Affairs, Attorney General of Indonesia, Bareskrim Police Headquarters and others.

2. The Government undertakes cooperation and coordination among state institutions in order to combat trafficking crimes committed by Ministry of Women Empowerment and Child Protection, Ministry of Justice and Human Rights, Ministry of Social Affairs, Indonesian National Police, Joint Agreement of State Minister of Women Empowerment, Minister of Health, The Minister of Social Affairs and the Chief of Police of the Republic of Indonesia on Integrated Services of Victims of Violence Against Women and Children, realized by establishing Integrated Service Centers at several Central and Regional public hospitals and Police hospitals.

3. The Government undertakes international cooperation, one of which is a workshop between Indonesia and Malaysia in cooperation with PTPPO across state borders between Sabah and East Kalimantan and followed up with Coordination between Task Force PPTPPO Indonesia

4. To socialize the dangers of trafficking in persons to the general public such as those conducted by the Immigration Bureau of Pemalang which socialize the prevention of trafficking in persons related to the provision of Travel Documents of the Republic of 
Indonesia to relevant institutions such as Polsek, Koramil, Camat and other Regional Government agencies in the region Batang Regency, Pekalongan City and Pekalongan Regency.

\section{CONCLUSION}

Factors behind the occurrence of crime children trafficking is actually influenced by various factors such as consumptive behavior, employment, education, migration, family conditions, mass media, advances in information technology, transportation and so on but of all these factors which most affect the cause of the crime of children trafficking is the economic factor of children who are in a family economic condition is less so classified as poor families when driven by economic needs, whether for survival or desire for a better life can cause many children become victims a human trafficking crime that originated as a victim of fraud, because of compulsion, and because of his own desires and the factors that most influence the cause of the second crime of children trafficking is the culture of society where the child is the right property that can be treated at will by their parents, gender inequality or the position of women who are considered inferior still grow in the middle of life of some people of Indonesia.

Actions taken by the government as an effort to prevent and overcome human trafficking crime is to make various laws regulating the criminal acts of trafficking in persons, one of which is Law Number 21 Year 2007 on the Eradication of Crime People Trafficking. The other real actions undertaken by the government are by conducting a national coordination meeting on the protection of women and children by 2013, cooperating and coordinating among state institutions in the context of combating trafficking crimes, conducting international cooperation and disseminating the dangers of trafficking in persons to the general public.

It is expected that law enforcement officers such as Police, Attorney and Court are more serious in handling human trafficking crime cases by enforcing Law Number 21 of 2007 with maximum. Therefore, in imposing the imprisonment and the fine to the defendant is done by giving maximum punishment (setingi tinggi), it is intended in addition to providing a deterrent effect also shows the seriousness for law enforcers (especially judges) to make efforts to prevent the case of trafficking can be categorized one the heavily classified cases of punishment or in other words no tolerance for human trafficking cases.

It is expected that the central and local government or related institutions can provide problem solving from various factors driving the occurrence of Human Trafficking Crime. Either in Penal efforts or Preventive efforts (criminal law approach) as well as non penal or repressive efforts (efforts outside the criminal law).

It is expected that the central and local government can realize various laws and regulations that contain the provisions on human trafficking crime with maximum in accordance with the provisions that have been stipulated as well as possible that is by continuously doing prevention, handling and handling of human trafficking crime and continue to socialize about the dangers of human trafficking crimes to the public so that human trafficking can be dealt with maximally.

\section{BIBLIOGRAPHY}

Arif Gosita, 2007, Masalah Korban Kejahatan, FHUI Cet. Ke IV, Jakarta.

Didi Sukardi, 2016, Perlindungan Hukum anak Korban Penelantaran Orang Tua Berbasis Hukum Positif dan Islam, Mahkamah, Vol.1 No.2 Desember E-ISSN: 2502-6595

Ahmad Syaufi, 2011, Perlindungan Hukum Terhadap Perempuan dan Anak Korban Tindak Pidana Perdagangan Orang, Muwazah, Vol.3, No.2, Desember

David E. Guinn, "Defining the Problem of Trafficking: The Interplay of US Law, Donor, and NGO Engagement and the Local Context in Latin America", Vol. 30. 
I.S. Susanto, 2011, “Kriminologi”, Genta Publishing, Yogyakarta.

O. Oko Elechi, T.Y. Okosun, and Job E. Ngwe, "Factors Vitiating Against the Effectiveness of the Nigeria Police in Combating the Criminal Exploitation of Children and Women",AJCJS; Volume 3, No. 1, July 2007, ISSN 1554-3897

Ririen Ambarsari, Faniko Andiyansyah, Anugrah Adiputro Soewandi, "Kajian Yuridis Tentang Perlindungan Hukum Terhadap Perempuan dan Anak Korban Human Trafficking" Vol.1 No.1 Juni 2016 ISSN: 2527-6654.

Topo Santoso dan Eva Achjani Zulfa, 2011, "Kriminologi”, PT.Rajagrafindo Persada, Cet. Ke II, Jakarta.

http://www.kpai.go.id/artikel/temuan-dan-rekomendasi-kpai-tentang-perlindungan-anak-di-bidang-perdagangan-anak-trafficking-dan-eksploitasi-terhadap-anak/ 